\title{
Improvement of growth performance of Amorpha fruticosa under contrasting regime of water and fertilizer in coal- contaminated spoils using response surface methodology
}

\author{
Rana Roy ${ }^{1,2}$, Mohammad Golam Mostofa ${ }^{3}$, Jinxin Wang ${ }^{1,4^{*}}$, Ashim Sikdar ${ }^{1,2}$ and Tanwne Sarker ${ }^{5}$
}

\begin{abstract}
Background: Water availability and nutrient-status of soils play crucial roles in seedling establishment and plant survival in coal-spoiled areas worldwide. Restoration of spoils pertains to the application of proper doses of nutrients and water, and selection of particular plant species for efficient revegetation. This study aimed at examining the potential effects of different combinations of soil-water and fertilizers (nitrogen, $\mathrm{N}$ and phosphorus, $\mathrm{P}$ ) on morpho-physiological and biochemical attributes of Amorpha fruticosa grown in coal-mined spoils. Three factors five-level central-composite-design with optimization technique response surface methodology (rsm) was used to optimize water irrigation and fertilizer application strategies.

Results: Our results revealed a strong correlation between experimental data and predicted values developed from the rsm model. The best responses of A. fruticosa in terms of plant height, stem diameter, root length, and dry biomass were observed under a high-water regime. Low-water regime caused a notable reduction in growth-associated parameters, and fertilization with either $\mathrm{N}$ or $\mathrm{P}$ did not show positive effects on those parameters, indicating that soil-water was the most influential factor for growth performance. Leaf water potential, gas-exchange parameters, and chlorophyll content significantly increased under high levels of soil-water, $\mathrm{N}$ and $\mathrm{P}$, suggesting a synergistic effect of these factors for the improvement of photosynthesis-related parameters. At low soil-water contents and N-P fertilizer application levels, enhanced accumulation of malondialdehyde and proline indicated that $A$. fruticosa suffered from oxidative and osmotic stresses. Amorpha fruticosa also responded to oxidative stress by accelerating the activities of superoxide dismutase, catalase, and peroxidase. The effects of both fertilizers relied on soilwater, and fertilization was most effective under well-watered conditions. The maximum growth of A. fruticosa was observed under the combination of soil-water, N-dose and P-dose at $76 \%$ field capacity, $52.0 \mathrm{mg} \mathrm{kg}^{-1}$ and $49.0 \mathrm{mg} \mathrm{kg}^{-1}$, respectively.

\footnotetext{
*Correspondence: jxwang2002@126.com; jwang118@nwsuaf.edu.cn

${ }^{1}$ College of Natural Resources and Environment, Northwest A\&F University, Yangling, Shaanxi 712100, People's Republic of China

${ }^{4}$ Key Laboratory of Plant Nutrition and the Agri-Environment in Northwest China, Ministry of Agriculture, Yangling 712100, People's Republic of China Full list of author information is available at the end of the article
}

(c) The Author(s). 2020 Open Access This article is licensed under a Creative Commons Attribution 4.0 International License, which permits use, sharing, adaptation, distribution and reproduction in any medium or format, as long as you give appropriate credit to the original author(s) and the source, provide a link to the Creative Commons licence, and indicate if changes were made. The images or other third party material in this article are included in the article's Creative Commons licence, unless indicated otherwise in a credit line to the material. If material is not included in the article's Creative Commons licence and your intended use is not permitted by statutory regulation or exceeds the permitted use, you will need to obtain permission directly from the copyright holder. To view a copy of this licence, visit http://creativecommons.org/licenses/by/4.0/. The Creative Commons Public Domain Dedication waiver (http://creativecommons.org/publicdomain/zero/1.0/) applies to the data made available in this article, unless otherwise stated in a credit line to the data. 
(Continued from previous page)

Conclusion: Our results demonstrate that rsm effectively designed appropriate doses of water and N-P fertilizer to restore coalspoiled soils. Furthermore, A. fruticosa responded to low-water and fertilizer-shortage by upregulating defensive mechanism to avoid damage induced by such deficiencies. Finally, our findings provide effective strategies for revegetation of coalcontaminated spoils with A. fruticosa using appropriate doses of water and N-P fertilizers.

Keywords: Amorpha fruticosa, Central composite design, Coal-mined spoil, Growth performance, Nutrients, Revegetation, Soilwater

\section{Background}

Water-shortage is considered as one of the major ecological limiting factors, affecting the restoration of vegetation and plant productivity. Simultaneously, the soil-water deficiency is usually connected with the unobtainability of nutrients in arid and semi-arid areas of the world [1]. Drought along with nutrient deficiency limits vegetation establishment, and the relationships between vegetation restoration and soil-moisture availability have recently gathered significant attention because of their importance in re-establishment of an ecosystem in the drought-prone areas [2-4]. The northwest-part of China considerably covers a big region of the world's dry-lands [5]. Seedling establishment and plant growth in this region largely depend on natural precipitation [5]. Moreover, this region comprises of many coalmine areas, contributing around 70\% of China's coal production. Coal-mining leads to serious ecological and environmental problems, such as removal of the earth-surface cover, damage of plant roots, destruction of vegetation and turning of coal-mining areas into deserts [6, 7]. Thus, the coal-mined spoils of northwest-part of China could be an appropriate resource to explore the possibility of ecosystem restoration using particular plant species and appropriate doses of water and fertilizers.

Artificial ecological engineering (revegetation) is the appropriate method for restoration of ecology in an abandoned coal gob piles in order to improve the environmental conditions. However, restoration of such kind of degraded areas is very challenging and considered as a daunting task for the environmentalists [8]. An adequate amount of soil-moisture and nutrients is the key to support plant growth and development in dry-land areas [9]. Moreover, the development of a self-sustaining revegetation ecosystem also depends on the selection of suitable plant species, which, together with effective treatment strategies using soil-water and fertilizers can help increase restoration effectiveness [10]. The plants which are originated in the desert-environment have better adaptable photosynthetic systems compared to plants that originated in other normal environments. To continue life cycles in the desert areas, plants develop several survival mechanisms associated with morphological, physiological and biochemical adaptations [11, 12]. Amorpha fruticosa is a deciduous shrub (1-6 m tall) and able to grow in diverse environmental conditions [13]. It is a commonly used shrub for revegetation in Loess Plateau of China because of its drought resistance and adaptation capabilities under infertile conditions. A. fruticosa is frequently cultivated in areas after landslides and escarpments, and for stabilization of the soils on railway embankments, as it's roots play important roles in the reduction of soil erosion. It can also effectively dwells in degraded-environments in the form of brushes with its seed and suckers [14].

Ecological problems due to coal mining and the vegetation reestablishment in coal-mining areas are very important environmental issues, urging in-depth research for the sustainable environment $[8,15]$. Numerous findings reported the impacts of soil-water and nutrients on the growth and development of various crops in coalmined areas [16-18]. The results suggested that the coupling effects of soil-water and fertilizers played vital roles on plant growth for the restoration of vegetation. To our knowledge, the combinatorial effects of soil-water and fertilizers on desert shrubs in coal-mined spoils have rarely been performed. Hence, it is worth investigating the growth response of $A$. fruticosa planted in coal-mined spoils concerning different strategies of water and fertilizer applications. Thus, the objective of this study was to evaluate the growth and development of $A$. fruticosa in response to different combination of water (W) and fertilizers (nitrogen, $\mathrm{N}$ and phosphorus, $\mathrm{P}$ ) using central composite design (CCD) with optimization technique response surface methodology (rsm), and to find out optimum water and fertilizer doses for vegetation restoration in a coalcontaminated desert area in China. For this purpose, we have examined the effect of $\mathrm{W}, \mathrm{N}$ and $\mathrm{P}$ on the morphological, physiological and biochemical responses of $A$. fruticosa by considering plant height, stem diameter, root length, dry biomass, root/shoot $(\mathrm{R} / \mathrm{S})$ ratio of biomass, leaf water potential (LWP), photosynthesis rate $\left(P_{\mathrm{n}}\right)$, transpiration rate $\left(T_{\mathrm{r}}\right)$, stomatal conductance $\left(G_{\mathrm{s}}\right)$, water use efficiency (WUE), the levels of chlorophyll (Chl), malondialdehyde (MDA), and proline (Pro), and the activities of antioxidant enzymes superoxide dismutase (SOD), catalase (CAT) and peroxidase (POD).

\section{Results}

Effects on morphological growth responses of $A$. fruticosa The maximum increase of plant height $(101.23 \mathrm{~cm})$, stem diameter $(7.26 \mathrm{~mm})$, root length $(73.12 \mathrm{~cm})$ and dry 
biomass $(42.37 \mathrm{~g})$ were recorded under the treatments of W (80\% Field capacity (FC)), N (60 $\left.\mathrm{mg} \mathrm{kg}^{-1}\right)$ and P (90 $\mathrm{mg} \mathrm{kg}^{-1}$ ) (Table 1). The minimum root-shoot (R/S) biomass ratio of 1.51 was observed when the plants were treated with the highest dose of W $(80 \% \mathrm{FC})$, and medium doses of $\mathrm{N}\left(60 \mathrm{mg} \mathrm{kg}^{-1}\right)$ and $\mathrm{P}\left(90 \mathrm{mg} \mathrm{kg}^{-1}\right)$ fertilizers (Table 1). The lowest increment of plant height $(52.04 \mathrm{~cm})$ was recorded under the combination of $\mathrm{W}, \mathrm{N}$ and $\mathrm{P}$ at $48.1 \% \mathrm{FC}, 95.68 \mathrm{mg} \mathrm{kg}^{-1}$ and $36.49 \mathrm{mg} \mathrm{kg}^{-1}$, respectively (Table 1). The increase of stem diameter was $4.83 \mathrm{~mm}$ when the plants exposed to medium W $(60 \% \mathrm{FC})$ and $\mathrm{N}$ $\left(60 \mathrm{mg} \mathrm{kg}^{-1}\right)$, and highest $\mathrm{P}$ doses $\left(180 \mathrm{mg} \mathrm{kg}^{-1}\right)$ (Table 1$)$. On the other hand, the lowest root length $(44.96 \mathrm{~cm})$ was recorded when the plants were treated with medium $\mathrm{W}$ (60\% FC), $\mathrm{N} \mathrm{(60} \mathrm{mg} \mathrm{kg}^{-1}$ ) and P (90 $\left.\mathrm{mg} \mathrm{kg}^{-1}\right)$ doses (Table $1)$. The minimum dry biomass $(24.0 \mathrm{~g})$ and highest $\mathrm{R} / \mathrm{S}$ biomass ratio (2.09) were observed at W (40\% FC), N (60 mg $\mathrm{kg}^{-1}$ ) and $\mathrm{P}\left(90 \mathrm{mg} \mathrm{kg}^{-1}\right)$ doses (Table 1). Positive values of the parameter coefficients $\mathrm{W}\left(\mathrm{a}_{1}\right)$ and $\mathrm{N}\left(\mathrm{a}_{2}\right)$ exhibited positive effect of $\mathrm{W}$, and $\mathrm{N}$ on plant height, stem diameter, and root length, and the relative magnitude was: $\mathrm{W}>\mathrm{N}$ (Table 3). In contrast, $\mathrm{P}\left(\mathrm{a}_{3}\right)$ had no positive effect on the above-mentioned parameters (Table 3). For plant dry biomass parameter coefficients, $\mathrm{W}, \mathrm{N}$, and $\mathrm{P}$ had a positive effect with $\mathrm{W}$ having the greatest effect, followed by $\mathrm{N}$ and $\mathrm{P}$ (Table 3). The coefficient $\mathrm{P}$ was positive for $\mathrm{R} / \mathrm{S}$ biomass ratio in contrast $\mathrm{W}$ and $\mathrm{N}$ had a negative effect (Table 3).

Effects on leaf water potential, gas-exchange parameters, and chlorophyll contents of $A$. fruticosa

The maximum increase and decrease of leaf water potential (LWP) (- 1.08 MPa and - 4.81 MPa, respectively) were obtained at medium $\mathrm{N}\left(60 \mathrm{mg} \mathrm{kg}^{-1}\right)$ and $\mathrm{P}\left(90 \mathrm{mg} \mathrm{kg}^{-1}\right)$, but at highest and lowest W (80 and 40\% FC) level, respectively (Table 1). The maximum values obtained for photosynthesis rate $\left(P_{\mathrm{n}}\right)$ and transpiration rate $\left(T_{\mathrm{r}}\right)$ were $13.52\left(\mu \mathrm{mol} \mathrm{m}{ }^{-2} \mathrm{~s}^{-1}\right)$ and $5.90\left(\mathrm{mmol} \mathrm{m}^{-2} \mathrm{~s}^{-1}\right)$, respectively, under the treatments of $\mathrm{W}$ at $71.9 \% \mathrm{FC}, \mathrm{N}$ at $95.68 \mathrm{mg} \mathrm{kg}^{-1}$ and $\mathrm{P}$ at $143.51 \mathrm{mg} \mathrm{kg}^{-1}$ (Table 1 ). In contrast, the lowest value of $P_{\mathrm{n}}\left(10.78 \mu \mathrm{mol} \mathrm{m} \mathrm{m}^{-2} \mathrm{~s}^{-1}\right)$ and $\left(G_{\mathrm{s}}\right)$ $\left(0.17 \mathrm{~mol} \mathrm{~m}^{-2} \mathrm{~s}^{-1}\right)$ were recorded under the combinations of W, N, and P (48.1\% FC, $24.32 \mathrm{mg} \mathrm{kg}^{-1}$ and $143.51 \mathrm{mg}$ $\mathrm{kg}^{-1}$, respectively) (Table 1 ). The treatment with $\mathrm{W}$ (48.1\% FC), $\mathrm{N}$ (95.68 $\mathrm{mg} \mathrm{kg}^{-1}$ ) and $\mathrm{P}\left(143.51 \mathrm{mg} \mathrm{kg}^{-1}\right)$ resulted in minimum $T_{\mathrm{r}}\left(3.64 \mathrm{mmol} \mathrm{m} \mathrm{m}^{-2} \mathrm{~s}^{-1}\right)$ and maximum water use efficiency (WUE) $\left(3.48 \mu \mathrm{mol} \mathrm{mmol}^{-1}\right)$ (Table 1). All coefficients for LWP, $P_{\mathrm{n}}$, and $T_{\mathrm{r}}$ were positive (Table 3). Although $\mathrm{W}$ and $\mathrm{N}$ positively influenced $G_{\mathrm{s}}$, WUE was effectively increased by $\mathrm{N}$ only. For $G_{\mathrm{s}}$ and WUE, $\mathrm{P}$ did not show any positive effect (Table 3 ).

The minimum levels of chlorophyll (Chl) $a\left(2.16 \mathrm{mgg}^{-1}\right.$ fresh weight (FW)), Chl $b\left(1.06 \mathrm{mg} \mathrm{g}^{-1} \mathrm{FW}\right)$ and total Chls $\left(3.22 \mathrm{mg} \mathrm{g}^{-1} \mathrm{FW}\right)$ were observed in response to the treatments with $\mathrm{W}$ at $60 \% \mathrm{FC}, \mathrm{N}$ at $0 \mathrm{mg} \mathrm{kg}^{-1}$ and $\mathrm{P}$ at $90 \mathrm{mg}$ $\mathrm{kg}^{-1}$ (Table 2). The highest levels of Chl $a$ (2.69 $\mathrm{mg} \mathrm{g}^{-1}$ FW) and total Chl (4.69 $\left.\mathrm{mg} \mathrm{g}^{-1} \mathrm{FW}\right)$ were obtained in response to the treatments with $\mathrm{W}$ at $80 \% \mathrm{FC}, \mathrm{N}$ at $60 \mathrm{mg}$ $\mathrm{kg}^{-1}$ and $\mathrm{P}$ at $90 \mathrm{mg} \mathrm{kg}^{-1}$ (Table 2). Chl $a$, Chl $b$ and total Chl contents in $A$. fruticosa leaves significantly increased by the addition of $\mathrm{W}, \mathrm{N}$, and $\mathrm{P}$, where $\mathrm{N}$ had the maximum positive impact followed by W and P (Table 3 ).

\section{Effects on malondialdehyde and proline accumulation,} and the activities of antioxidant enzymes of $A$. fruticosa The malondialdehyde (MDA) content of A. fruticosa seedlings was suppressed by all 3 factors; however, proline (Pro) content was considerably decreased by W and $\mathrm{P}$ (Table 3). Among the factors, $\mathrm{W}$ was most influential for decreasing MDA and Pro contents in the leaves of $A$. fruticosa (Table 3). The minimum MDA content of $23.34 \mu \mathrm{mol} \mathrm{g}^{-1} \mathrm{FW}$ was recorded with $\mathrm{W}$ at $71.9 \% \mathrm{FC}$, $\mathrm{N}$ at $95.68 \mathrm{mg} \mathrm{kg}^{-1}$ and $\mathrm{P}$ at $36.49 \mathrm{mg} \mathrm{kg}^{-1}$ (Table 2). In contrast, the maximum MDA content was observed under the combinations of $\mathrm{W}, \mathrm{N}$, and $\mathrm{P}(48.1 \% \mathrm{FC}$, $95.68 \mathrm{mg} \mathrm{kg}^{-1}$ and $143.51 \mathrm{mg} \mathrm{kg}^{-1}$, respectively) (Table $2)$. The highest W (80\% FC) and medium N (60 mg $\mathrm{kg}^{-1}$ ) and $\mathrm{P}\left(90 \mathrm{mg} \mathrm{kg}^{-1}\right)$ doses represented minimum accumulation of Pro $\left(1.54 \mu \mathrm{mol} \mathrm{g}^{-1}\right.$ FW) in the leaves of experimental seedlings; while the maximum Pro content of $5.15 \mu \mathrm{mol} \mathrm{g}^{-1} \mathrm{FW}$ was obtained with $\mathrm{W}$ at $48.1 \% \mathrm{FC}$, $\mathrm{N}$ at $95.68 \mathrm{mg} \mathrm{kg}^{-1}$ and $\mathrm{P}$ at $36.49 \mathrm{mg} \mathrm{kg}^{-1}$ (Table 2).

The superoxide dismutase (SOD) $\left(154.68 \mathrm{Ug}^{-1} \mathrm{FW}\right)$ and catalase (CAT) (196.15 $\left.\mathrm{U} \mathrm{min}^{-1} \mathrm{~g}^{-1} \mathrm{FW}\right)$ activities considerably increased under the treatment with $\mathrm{W}$ at $40 \% \mathrm{FC}, \mathrm{N}$ at $60 \mathrm{mg} \mathrm{kg}^{-1}$ and $\mathrm{P}$ at $90 \mathrm{mg} \mathrm{kg}^{-1}$. The minimum SOD activity (89.22 $\left.\mathrm{Ug}^{-1} \mathrm{FW}\right)$ was observed at medium W (60\% FC), N (60 $\left.\mathrm{mg} \mathrm{kg}^{-1}\right)$, and P (90 mg $\mathrm{kg}^{-1}$ ) levels, whereas the minimum CAT activity $\left(152.97 \mathrm{U} \mathrm{min}^{-1} \mathrm{~g}^{-1} \mathrm{FW}\right)$ was recoreded with $\mathrm{W}$ at $71.9 \% \mathrm{FC}, \mathrm{N}$ at $24.32 \mathrm{mg} \mathrm{kg}^{-1}$ and $\mathrm{P}$ at $143.51 \mathrm{mg} \mathrm{kg}^{-1}$. The lowest peroxidase (POD) activity $\left(132.75 \mathrm{U} \mathrm{min}^{-1}\right.$ $\left.\mathrm{g}^{-1} \mathrm{FW}\right)$ in the leaves of $A$. fruticosa was observed with the combinations of $\mathrm{W}, \mathrm{N}$, and $\mathrm{P}(71.9 \% \mathrm{FC}, 95.68 \mathrm{mg}$ $\mathrm{kg}^{-1}$ and $36.49 \mathrm{mg} \mathrm{kg}^{-1}$, respectively). However, the POD activity significantly increased $\left(254.66 \mathrm{U} \mathrm{min}^{-1} \mathrm{~g}^{-1}\right.$ FW) in response to the treatments with $\mathrm{W}$ at $48.1 \% \mathrm{FC}$, $\mathrm{N}$ at $95.68 \mathrm{mg} \mathrm{kg}^{-1}$ and $\mathrm{P}$ at $143.51 \mathrm{mg} \mathrm{kg}^{-1}$ (Table 2). The activities of SOD and POD were decreased by W and $\mathrm{N}$; while CAT activity was considerably decreased by $\mathrm{W}$ and $\mathrm{P}$ (Table 3 ).

\section{Interactive effect of process variables on morphological parameters}

The mutual effect of $\mathrm{W}, \mathrm{N}$, and $\mathrm{P}$ over plant height and stem diameter displayed that plant height and stem diameter increased linearly with W rising from 40 to $80 \%$ FC. At low W dose (40\% FC), increment of $\mathrm{N}$ and $\mathrm{P}$ doses showed a little positive effect on the elevation of 


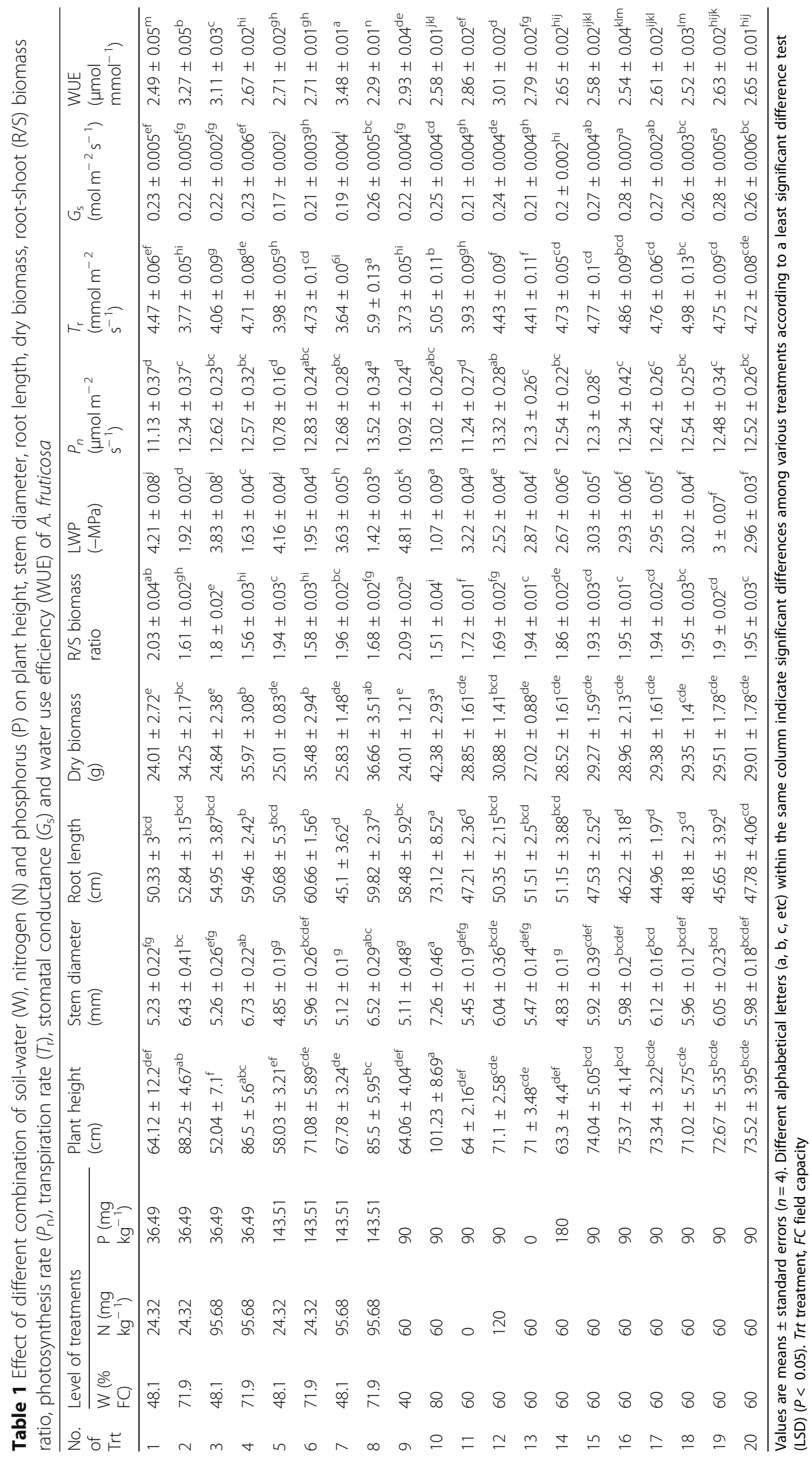




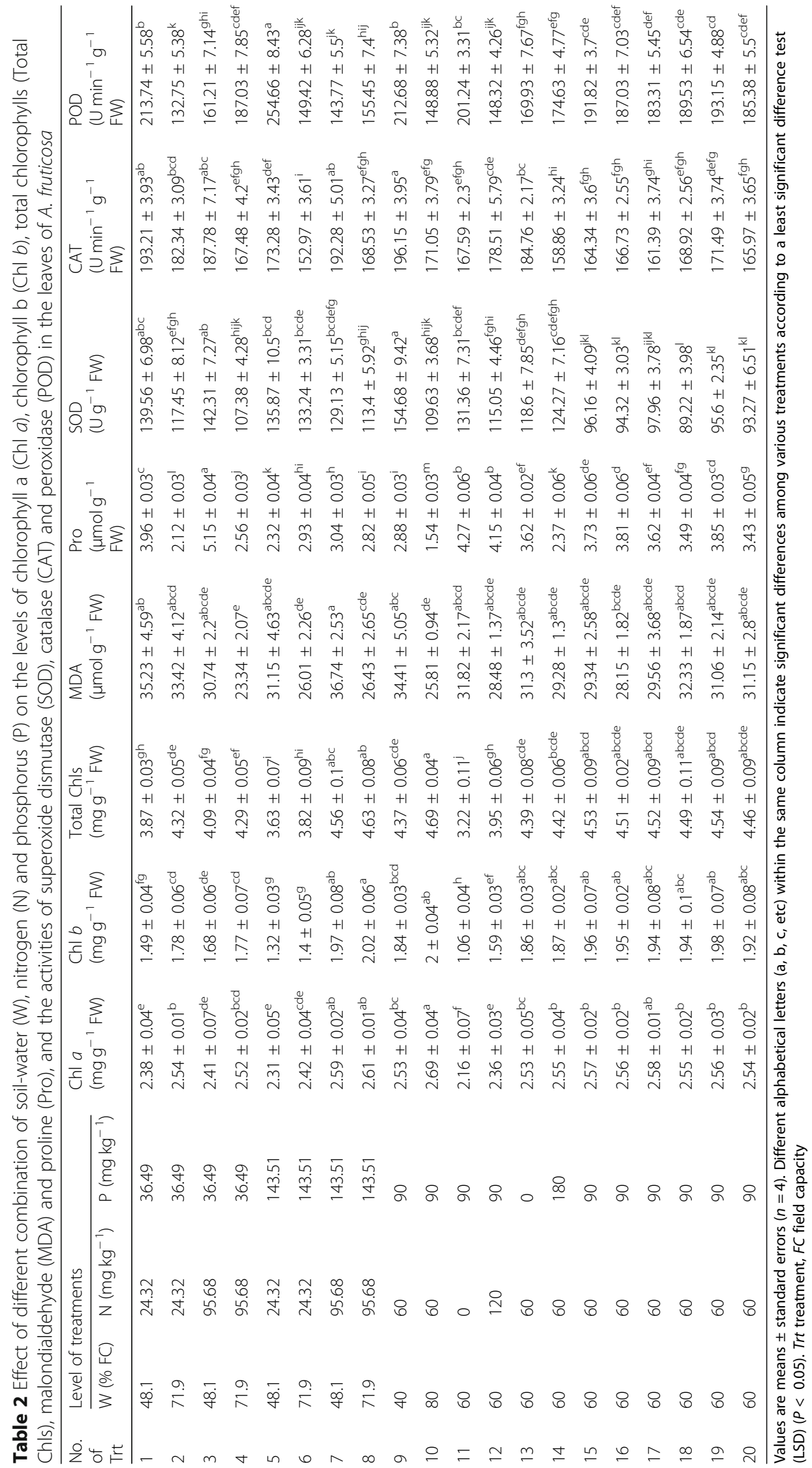


Table 3 Parameter coefficients of eq. $\left(Y=a_{0}+a_{1} x_{1}+a_{2} x_{2}+a_{3} x_{3}+a_{4} x_{1} x_{2}+a_{5} x_{1} x_{3}+a_{6} x_{2} x_{3}+a_{7} x_{1}{ }^{2}+a_{8} x_{2}{ }^{2}+a_{9} x_{3}{ }^{2}\right)$ for plant height $\left(R_{1}\right)$, stem diameter $\left(R_{2}\right)$, root length $\left(R_{3}\right)$, total biomass $\left(R_{4}\right)$, Root-shoot biomass ratio $\left(R_{5}\right)$, leaf water potential $\left(R_{6}\right)$, photosynthesis rate $\left(R_{7}\right)$, transpiration rate $\left(R_{8}\right)$, stomatal conductance $\left(R_{9}\right)$, water use efficiency $\left(R_{10}\right)$, chlorophyll a $\left(R_{11}\right)$, chlorophyll b $\left(R_{12}\right)$, total chlorophyll $\left(R_{13}\right)$, malondialdehyde $\left(R_{14}\right)$, proline $\left(R_{15}\right)$, superoxide dismutase activity $\left(R_{16}\right)$, catalase activity $\left(R_{17}\right)$ and peroxidase activity $\left(R_{18}\right)$

\begin{tabular}{|c|c|c|c|c|c|c|c|c|c|c|c|c|c|c|c|c|c|}
\hline Y & $a_{0}$ & $a_{1}$ & $a_{2}$ & $a_{3}$ & $a_{4}$ & $a_{5}$ & $a_{6}$ & $a_{7}$ & $a_{8}$ & $a_{9}$ & $R^{2}$ & $\mathrm{R}_{a}^{2}$ & $R_{p}^{2}$ & $\mathrm{~F}$ & $P$ & CV & $\mathrm{AP}$ \\
\hline $\mathrm{R}_{1}$ & 73.35 & 11.12 & 1.63 & -1.57 & 1.88 & -3.48 & 4.75 & 3.14 & -2.20 & -2.34 & 0.990 & 0.981 & 0.950 & 113.09 & $<0.0001$ & 2.11 & 43.42 \\
\hline $\mathrm{R}_{2}$ & 6.0 & 0.64 & 0.16 & -0.17 & 0.07 & -0.02 & 0.06 & 0.08 & -0.07 & -0.28 & 0.992 & 0.985 & 0.963 & 147.34 & $<0.0001$ & 1.32 & 46.57 \\
\hline$R_{3}$ & 46.77 & 4.13 & 0.74 & -0.14 & 0.84 & 2.21 & -2.21 & 6.41 & 0.39 & 1.29 & 0.980 & 0.963 & 0.906 & 55.99 & $<0.0001$ & 2.59 & 26.90 \\
\hline $\mathrm{R}_{4}$ & 29.25 & 5.39 & 0.58 & 0.47 & 0.15 & -0.01 & -0.07 & 1.38 & 0.20 & -0.53 & 0.999 & 0.998 & 0.997 & 1344.44 & $<0.0001$ & 0.63 & 135.78 \\
\hline$R_{5}$ & 1.94 & -0.17 & -0.02 & 0.001 & 0.03 & 0.001 & 0.05 & -0.05 & -0.09 & -0.02 & 0.980 & 0.963 & 0.870 & 56.83 & $<0.0001$ & 1.8 & 24.19 \\
\hline$R_{6}$ & -2.99 & 1.11 & 0.21 & 0.06 & -0.01 & -0.01 & 0.04 & 0.02 & 0.04 & 0.08 & 0.999 & 0.998 & 0.998 & 1725.45 & $<0.0001$ & 1.16 & 156.85 \\
\hline $\mathrm{R}_{7}$ & 12.43 & 0.55 & 0.57 & 0.11 & -0.31 & 0.22 & 0.11 & -0.14 & -0.03 & 0.02 & 0.984 & 0.970 & 0.910 & 70.70 & $<0.0001$ & 1.04 & 32.12 \\
\hline$R_{8}$ & 4.80 & 0.38 & 0.16 & 0.13 & 0.36 & 0.38 & 0.04 & -0.14 & -0.21 & -0.07 & 0.987 & 0.975 & 0.950 & 84.14 & $<0.0001$ & 1.91 & 36.77 \\
\hline $\mathrm{R}_{9}$ & 0.27 & 0.01 & 0.008 & -0.006 & 0.004 & 0.01 & 0.008 & -0.01 & -0.02 & -0.02 & 0.976 & 0.955 & 0.917 & 46.15 & $<0.0001$ & 2.86 & 20.73 \\
\hline $\mathrm{R}_{10}$ & 2.59 & -0.11 & 0.05 & -0.04 & -0.30 & -0.19 & 0.04 & 0.06 & 0.13 & 0.05 & 0.990 & 0.981 & 0.977 & 111.66 & $<0.0001$ & 1.42 & 43.35 \\
\hline$R_{11}$ & 2.56 & 0.05 & 0.06 & 0.008 & -0.02 & -0.01 & 0.05 & 0.02 & -0.10 & -0.005 & 0.994 & 0.990 & 0.981 & 213.48 & $<0.0001$ & 0.48 & 62.01 \\
\hline$R_{12}$ & 1.95 & 0.06 & 0.17 & 0.0005 & -0.03 & -0.03 & 0.14 & -0.01 & -0.22 & -0.03 & 0.993 & 0.987 & 0.955 & 167.61 & $<0.0001$ & 1.68 & 46.73 \\
\hline$R_{13}$ & 4.51 & 0.11 & 0.23 & 0.008 & -0.05 & -0.05 & 0.19 & 0.007 & -0.33 & -0.04 & 0.996 & 0.993 & 0.982 & 325.74 & $<0.0001$ & 0.72 & 69.39 \\
\hline $\mathrm{R}_{14}$ & 30.29 & -2.86 & -1.04 & -0.42 & -1.35 & -0.78 & 2.57 & & & & 0.939 & 0.912 & 0.911 & 33.75 & $<0.0001$ & 3.29 & 21.55 \\
\hline$R_{15}$ & 3.65 & -0.46 & 0.15 & -0.35 & -0.20 & 0.60 & -0.13 & -0.51 & 0.19 & -0.23 & 0.963 & 0.929 & 0.782 & 28.79 & $<0.0001$ & 6.95 & 22.08 \\
\hline$R_{16}$ & 94.43 & -11.07 & -4.49 & 1.06 & -3.24 & 4.84 & -2.41 & 13.29 & 10.13 & 9.51 & 0.985 & 0.972 & 0.927 & 73.19 & $<0.0001$ & 2.74 & 24.82 \\
\hline$R_{17}$ & 166.46 & -8.59 & 2.39 & -6.39 & -1.61 & -1.61 & 6.86 & 6.16 & 2.43 & 1.99 & 0.963 & 0.930 & 0.853 & 28.85 & $<0.0001$ & 1.85 & 20.05 \\
\hline $\mathrm{R}_{18}$ & 188.01 & -18.75 & -14.07 & 1.21 & 27.97 & -4.79 & -13.33 & -2.65 & -4.77 & -5.66 & 0.993 & 0.987 & 0.973 & 161.49 & $<0.0001$ & 1.86 & 51.97 \\
\hline
\end{tabular}

plant height and stem diameter, whereas at high W dose (80\% FC), plant height and stem diameter significantly increased with the addition of $\mathrm{N}$ and $\mathrm{P}$ fertilizers (Fig. 1a, b, Additional file 1: Figure S1). The root length initially decreased with the decrease of W dose (from 80 to $60 \%$ FC), but after reaching a certain point (at $60 \% \mathrm{FC}$ ), it started increasing with the further reduction of $\mathrm{W}$ dose (Fig. 1c, Additional file 1: Figure S1). Under low W dose (40\% FC), N fertilizer did not express any significant effects, while at high $\mathrm{W}$ dose (80\% FC) addition of $\mathrm{N}$ fertilizer increased root length slowly (Fig. 1c, Additional file 1: Figure S1). Dry biomass of $A$. fruticosa seedlings significantly influenced in response to $\mathrm{W}$ dose regardless of the doses of $\mathrm{N}$ and $\mathrm{P}$ fertilizers. The positive influence of $\mathrm{N}$ on plant dry biomass was detected at a high $\mathrm{W}$ dose (80\% FC) (Fig. 1d). In contrast, under low (40\% FC) and high ( $80 \%$ FC) W doses, the addition of P-fertilizer slightly increased dry biomass, but continuous P-addition resulted in negative impacts (Fig. 1e). The R/S biomass ratio dramatically enhanced with the decline of W level, whereas $\mathrm{P}$ had no obvious effects on $\mathrm{R} / \mathrm{S}$ biomass ratio (Fig. 1f, Additional file 1: Figure S1).

\section{Interactive effect of process variables on LWP, gas-} exchange parameters, and chlorophyll contents It was observed that LWP significantly declined at low W condition (around 40 to $48.1 \% \mathrm{FC}$ ), and the addition of $\mathrm{N}$ and $\mathrm{P}$ fertilizers did not show any positive effects on the recovery of LWP (Fig. 2a, Additional file 2: Figure S2). A mutual effect of $\mathrm{W}$ with N-P fertilizers over $P_{\mathrm{n}}$ and $T_{\mathrm{r}}$ were observed, and the data showed that both $P_{\mathrm{n}}$ and $T_{\mathrm{r}}$ increased with the addition of $\mathrm{W}, \mathrm{N}$ and $\mathrm{P}$, and the maximum $P_{\mathrm{n}}$ and $T_{\mathrm{r}}$ were obtained at $\mathrm{W}(71.9 \% \mathrm{FC}), \mathrm{N}$ (95.68 $\mathrm{mg} \mathrm{kg}^{-1}$ ) and $\mathrm{P}$ (143.51 $\mathrm{mg} \mathrm{kg}^{-1}$ ) doses (Fig. 2b-d, Additional file 2: Figure S2). The $G_{\mathrm{s}}$ initially increased with $\mathrm{W}$ and $\mathrm{N}$ doses up to a certain level (W at 60\% FC and $\mathrm{N}$ at $60 \mathrm{mg} \mathrm{kg}^{-1}$ ), whereas it started to decline with the increase of $\mathrm{W}$ and $\mathrm{N}$ above this level (Fig. 2e). Under low W condition (48.1\% FC), WUE significantly increased with the increase of $\mathrm{N}\left(95.68 \mathrm{mg} \mathrm{kg}^{-1}\right)$ and $\mathrm{P}$ doses (143.51 $\mathrm{mg} \mathrm{kg}^{-1}$ ) (Fig. 1f, Additional file 2: Figure S2). The combined effect of $\mathrm{W}$ and $\mathrm{N}$, and $\mathrm{W}$ and $\mathrm{P}$ on $\mathrm{Chl} a, \mathrm{Chl}$ $b$, and total Chls indicated that under both low and high W levels, total Chl contents dramatically increased with the addition of $\mathrm{N}$, whereas the interactive effect of $\mathrm{W}$ and $\mathrm{P}$ had no significant influence on the levels of total $\mathrm{Chl}$ (Fig. 2g-h, Additional file 2: Figure S2).

\section{Interactive effect of process variables on MDA and pro contents, and antioxidant enzyme activities}

Under low W condition (48.1\% FC), the addition of $\mathrm{N}$ (95.68 $\mathrm{mg} \mathrm{kg}^{-1}$ ) and $\mathrm{P}\left(143.51 \mathrm{mg} \mathrm{kg}^{-1}\right)$ fertilizer dramatically increased MDA content in our experimental 


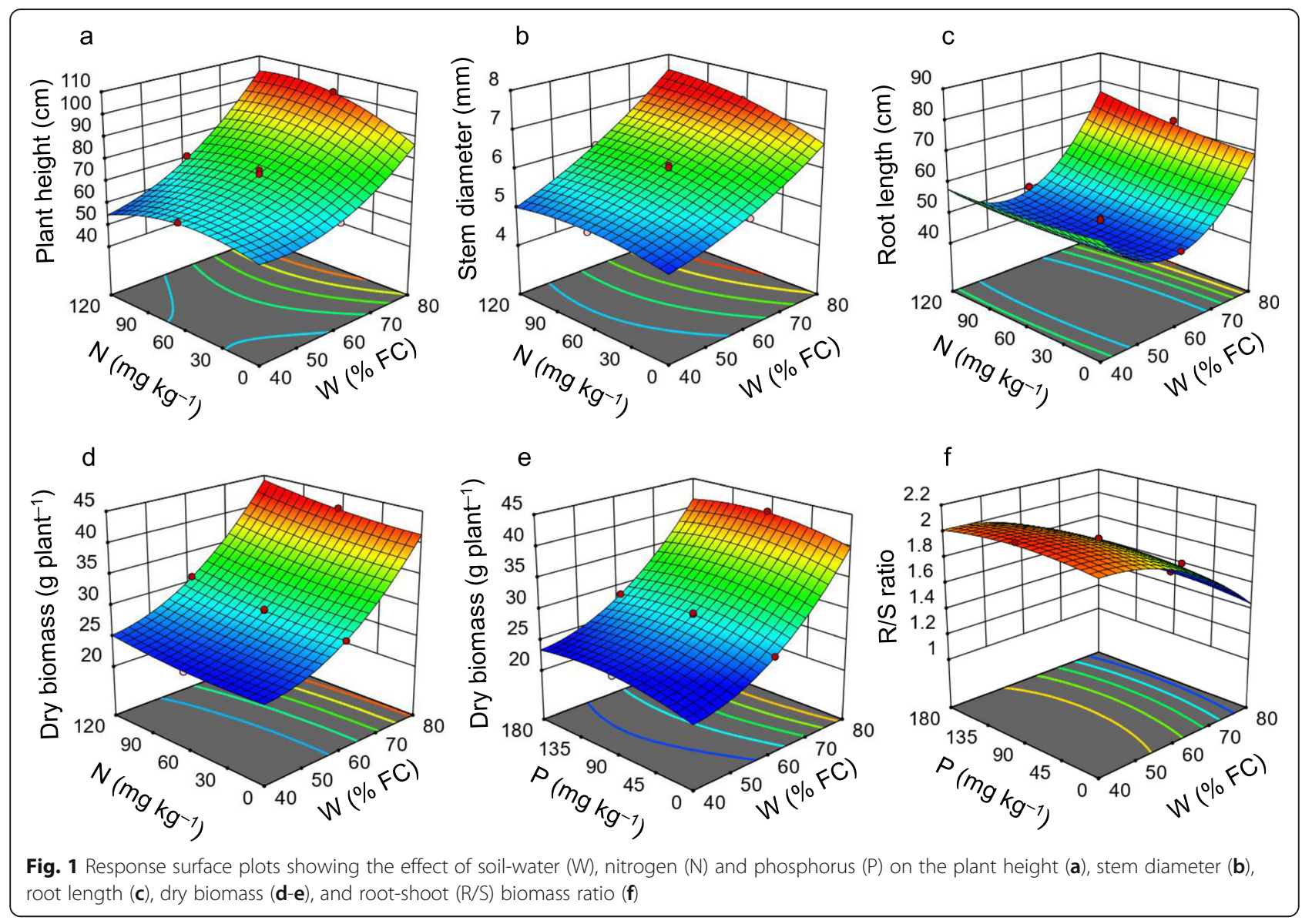

seedlings (Fig. 3a-b, Additional file 3: Figure S3). The highest W level (80\% FC) and medium N-P fertilizer (60 mg $\mathrm{kg}^{-1}$ and $90 \mathrm{mg} \mathrm{kg}^{-1}$, respectively) content was beneficial for the decrease of Pro content (Fig. 3c, Additional file 3: Figure S3).

The medium dose of W (60\% FC) and N-P fertilizer (60 $\mathrm{mg} \mathrm{kg}^{-1}$ and $90 \mathrm{mg} \mathrm{kg}^{-1}$, respectively) was suitable for the decrease of SOD activity (Fig. 3d, Additional file 3: Figure S3). When W level was $71.90 \%$ FC, CAT activity significantly decreased with the increase of $\mathrm{P}$ fertilizer (Fig. 3e, Additional file 3: Figure S3). Under low $\mathrm{W}$ and $\mathrm{N}$ doses (48.1\% FC and $24.32 \mathrm{mg} \mathrm{kg}^{-1}$, respectively), POD activity considerably increased. On the other hand, POD activity exhibited a decreasing trend in response to the increase of either W or N-P fertilizers (Fig. 3f, Additional file 3: Figure S3).

\section{Optimization of soil-water, nitrogen and phosphorus fertilizer}

According to CCD result, the optimum water and fertilizer rate to obtain maximum growth performance of A. fruticosa was determined by Derringer's desired function approach as follows: W of $75.68 \% \mathrm{FC}, \mathrm{N}$ of $51.64 \mathrm{mg} \mathrm{kg}^{-1}$, P of $49.49 \mathrm{mg} \mathrm{kg}^{-1}$ (Fig. 4). Under this condition, maximum plant growth was obtained (Fig. 4). Accurateness of the optimized condition was identified by comparing the average experimental values and the predicted values developed by the model. The desirability ramp obtained from optimal points is represented in Fig. 4.

\section{Discussion}

Our study demonstrated that maximum plant height, stem diameter, root length, and dry biomass were obtained at high soil-water content; and in this situation, the addition of N-P fertilizers significantly improved these growth associated attributes (Fig. 1a-e, Additional file 1: Figure S1). Low water levels caused a significant decline in plant dry biomass, and the effect of N-P fertilizers also depended on the availability of soil-water. At low waterlevel, increases in the doses of N-P fertilizers exhibited a little effect on the improvement of plant biomass, and the highest biomass was obtained at high water level (Fig. 1de; Additional file 1: Figure S1; Table 1). These findings indicated that due to scarcity of soil-water, nutrients present in the soil did not mobilize well, and plant roots could not uptake it adequately, which ultimately prevented water and nutrients flow through the xylem to the surrounding 


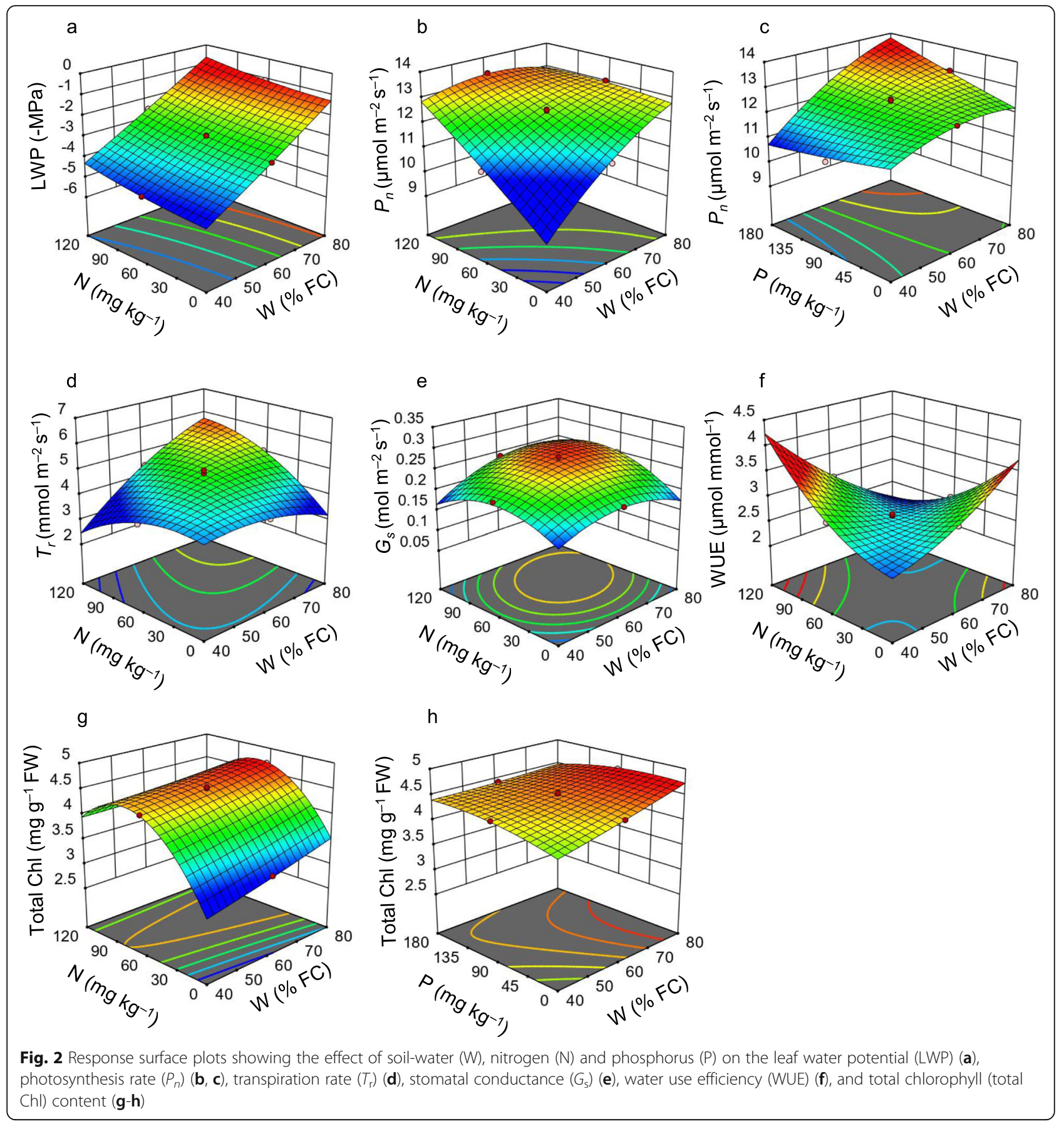

cells, as observed in other plant species under watershortage conditions [19-21]. Thus, the deficiency of nutrients and water eventually led to the inhibition of cell growth and elongation [21], as was also manifested in this study in terms of plant height and stem diameter (Table 1). However, the mutual influence of soil-water and N-P fertilizers considerably improved the functions of each other, which ultimately positively increased the plant height, stem diameter, root length and dry biomass of $A$. fruticosa, which were in parallel with previous studies $[22,23]$. The previous study reported that soil-water was the most important factor for plant morphological responses, and the effect of fertilizers like $\mathrm{N}$ and $\mathrm{P}$ on plant growth depends on soil-water content [24]. In this experiment, we observed that $R / S$ biomass ratio significantly increased under low water regime (Fig. 1f; Additional file 1: Figure S1; Table 1), indicating that under water and nutrient shortage conditions, carbon translocated from leaves to roots, thereby increasing R/S biomass ratio [25]. The increased $\mathrm{R} / \mathrm{S}$ biomass ratio during stress conditions could also be explained as one of the adaptive mechanisms 


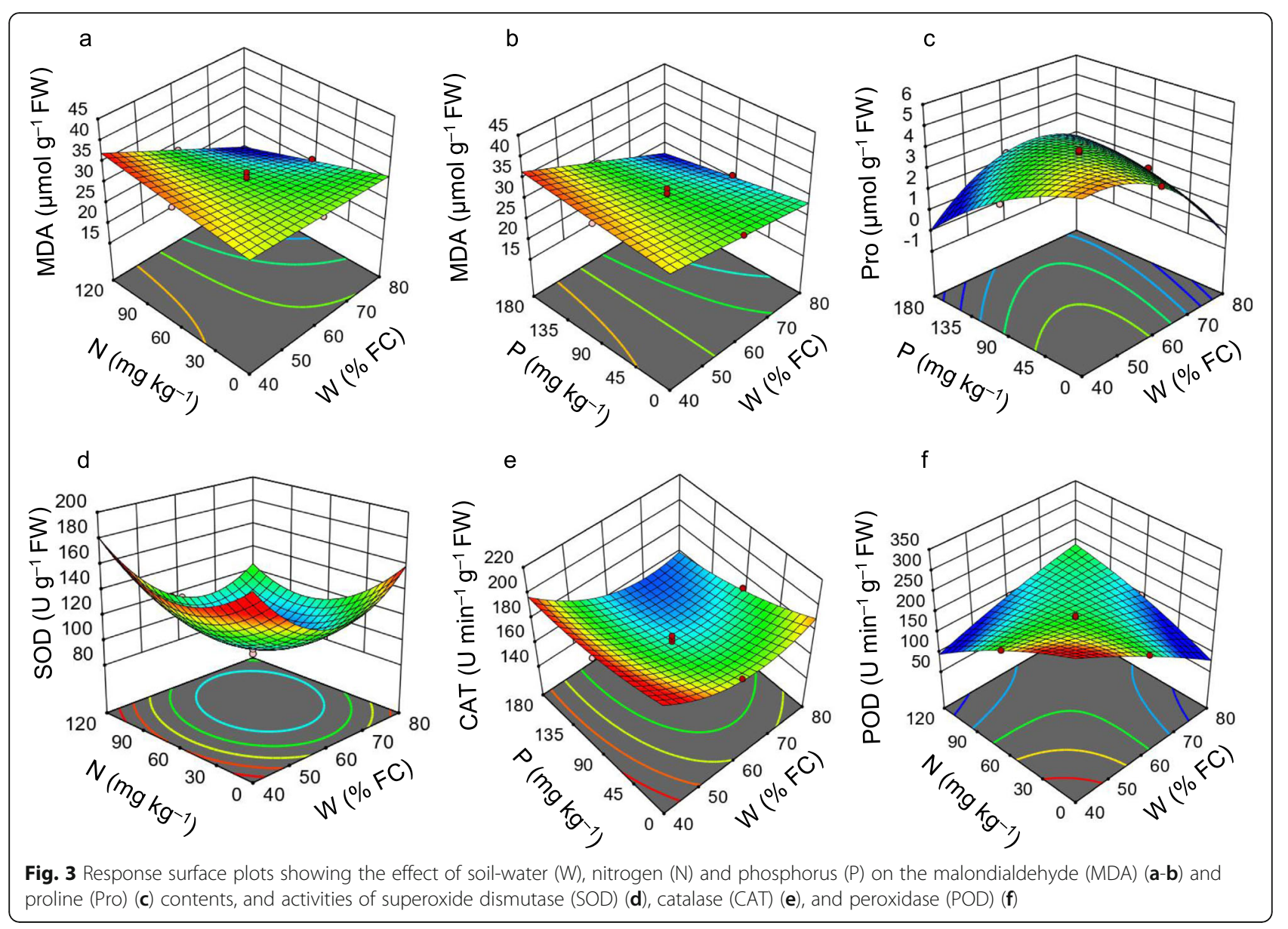

of plants to make greater root surfaces for absorbing much water and nutrients from soils [26]. However, other study reported that a greater R/S biomass ratio under stress conditions was resulted due to decreased shoot growth [27].

LWP acts as a powerful indicator of plants' water status, and a reduced level of water has been known to be involved in declining LWP in plant species [28]. Similarly, we observed that low level of water caused a severe reduction of LWP in A. fruticosa (Fig. 2a; Additional file 2: Figure S2; Table 1). Gas-exchange parameters are considered as important physiological parameters, having significant roles in plant growth and development. The status of gas-exchange parameters also correlated with the adaptive responses of the plants to cope under environmental assaults [3]. We also observed that interaction of high level of water with high-level fertilizers significantly increased $P_{\mathrm{n}}, T_{\mathrm{r}}$, and $G_{\mathrm{s}}$, whereas water and fertilizer limitations led to a considerable decline of those gas-exchange parameters (Fig. 2b-f; Additional file 2: Figure S2; Table 1). Under adverse environmental conditions, stomata of leaves are closed and $P_{\mathrm{n}}$ is inhibited, and thus, declined levels of $G_{\mathrm{s}}$ and $P_{\mathrm{n}}$ have been considered as indications of stomatal limitation [29]. Furthermore, a noticeable decrease in $G_{\mathrm{s}}$ during stress conditions indicate an efficient adaptive mechanism to control $T_{\mathrm{r}}$
[30]. The severe water-shortage condition is extremely unfavourable for absorbing and utilizing nutritional components from the soils by the plant root-systems [31]. Under well-watered conditions, a reasonable coupling model of water and fertilizers could be adopted to utilize $\mathrm{N}$ and $\mathrm{P}$ [32]. Our results corroborated with the findings of several reports, and indicated that high soil-water content and fertilizers positively increased $P_{\mathrm{n}}, G_{\mathrm{s}}$ and $T_{\mathrm{r}}$; however, plants are used to reduce these parameters in order to survive under water-shortage conditions [28, 33]. Our experimental results exhibited that during water-shortage conditions, WUE increased with the addition of N-P fertilizer, and the minimum WUE was detected under high soil-water and $\mathrm{N}$ $P$ fertilizer doses, which were in parallel with a previous report [34].

The status of Chl content is considered as the tolerance index of the plants under stressful conditions [35]. Total Chl $(\mathrm{Chl} a+\mathrm{Chl} b)$ content considerably decreased with the increasing level of water-shortage (Fig. 2g-h; Additional file 2: Figure S2; Table 2), indicating that $A$. fruticosa mounted an adaptive mechanism to protect themselves from the damage of low-water induced photo-inhibition [36]. Gallé and Feller [37] also reported that continuous drought led to decrease Chl content, 


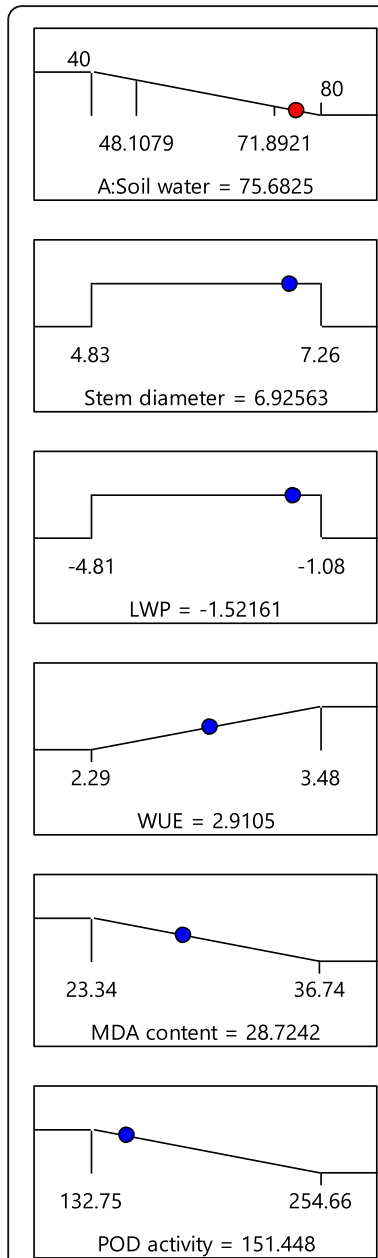

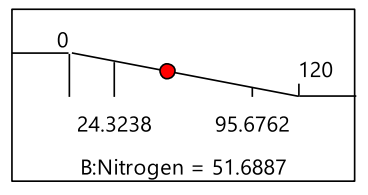
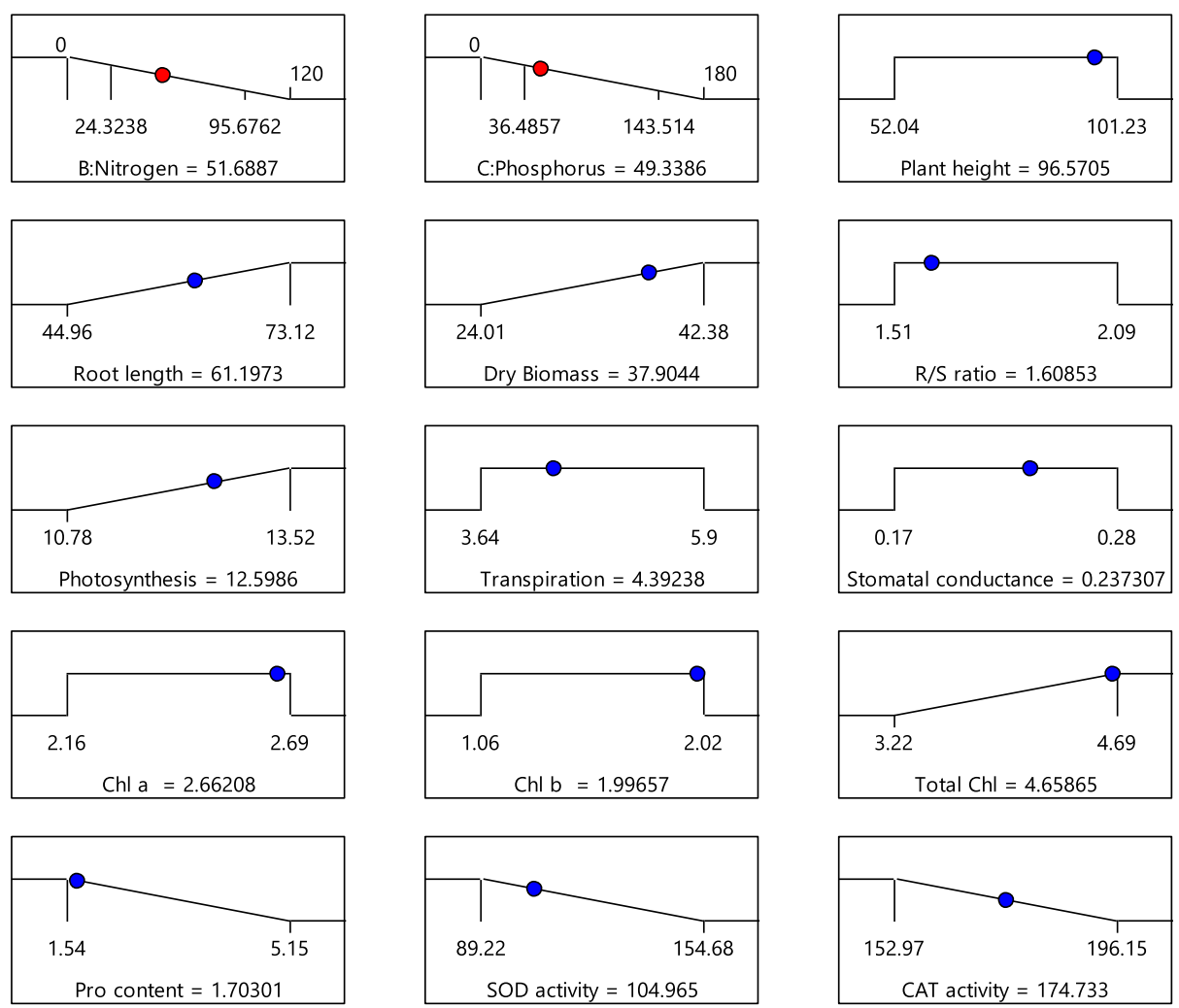

Desirability $=0.596$ Solution 1 out of 6

Fig. 4 Desirability ramp for optimization

reduce stomatal conductance, and finally reduce $P_{\mathrm{n}}$ in the leaves of Fagus sylvatica. However, together with N, soil-water significantly increased $\mathrm{Chl}$ content, whereas $\mathrm{P}$ did not show any positive effect on Chl content. Since N is an integral part of Chl molecules, $\mathrm{N}$-shortage conditions were associated with the reduced level of $\mathrm{Chl}$ and chlorosis-related symptoms in plants [38, 39].

We observed a considerable increase of lipid peroxidation product MDA and osmoprotectant Pro under watershortage condition compared to the well-watered conditions (Fig. 3a-c; Additional file 3: Figure S3; Table 2). These results suggest that water deficiency led to the production of ROS, which ultimately caused lipid peroxidation of the membrane, leading to greater production of MDA. However, MDA content decreased gradually with the addition of soil-water and N-P fertilizer, and the results showed that high W and N-P fertilizer doses contributed to drought tolerance by inhibiting the damage of cell membranes and enhancing osmoregulation in A. fruticosa seedlings. Saneoka et al. [40] also reported that MDA content in bentgrass (Agrostis palustris) was higher under drought conditions than those found in control condition, and MDA content decreased with the addition of $\mathrm{N}$ to the growth medium. Similarly, a water-deficient state resulted in osmotic stress, and A. fruticosa accumulated a high level of Pro to overcome the adverse effects of osmotic stress. Our results corroborated the findings of others in mulberry (Morus alba) and moth beans (Vigna aconitifolia) $[41,42]$, and suggested that water-stressed plants increased osmoprotective adaptation by accumulating high levels of osmoprotectants like Pro.

To protect from the deleterious effects of ROS produced under stressful conditions, plants normally increase their protective mechanisms against ROS by enhancing the activities of several enzymes, including SOD, CAT and POD [11]. A wealth of reports suggest that exposure of plants to drought led to the enhancement of the activities of antioxidant enzymes, such as SOD, CAT, and POD, and increased enzymatic responses represent a greater antioxidant capacity for providing drought resistance in plants [43-45]. A remarkable increase in SOD activity in the leaves of low W and high N-treated seedlings (Fig. 3d; 
Additional file 3: Figure S3; Table 2) indicated that $A$. fruticosa plants improved their antioxidative defence status to protect themselves from ROS-mediated damage. A significant rise in CAT and POD activities in the leaves of $A$. fruticosa plants under low $\mathrm{W}, \mathrm{N}$, and $\mathrm{P}$ treatments also implied that $A$. fruticosa plants responded well to water and nutrient shortage by activating antioxidant capacity (Fig. 3e-f; Additional file 3: Figure S3; Table 2).

The maximum growth performance of $A$. fruticosa was observed in response to the treatments with $\mathrm{W}$ at $75.68 \% \mathrm{FC}, \mathrm{N}$ at $51.64 \mathrm{mg} \mathrm{kg}^{-1}$ and $\mathrm{P}$ at $49.49 \mathrm{mg} \mathrm{kg}^{-1}$ (Fig. 4). In accordance with our results, Wang et al. [46] also demonstrated that microbial inoculum with inorganic fertilizer $\left(\mathrm{N}\right.$ at $61.73 \mathrm{mg} \mathrm{kg}^{-1}$ and $\mathrm{P}$ at $40.0 \mathrm{mg}$ $\mathrm{kg}^{-1}$ doses) significantly improved morphological, physiological, and antioxidant enzyme responses in Medicago sativa when grown in coal-mined spoils.

\section{Conclusion}

The levels of doses developed for W, N and P using rsm correlated with the growth performance of A. fruticosa, suggesting that rsm could be used as an effective tool to design the perfect combination of water and fertilizers for revegetation of coal-spoiled soils. Our results revealed that application of various doses of $\mathrm{W}, \mathrm{N}$ and $\mathrm{P}$ significantly altered growth-associated attributes, including shoot height, stem diameter, root length and dry biomass of A. fruticosa. Although all the three factors (W, $\mathrm{N}$ and $\mathrm{P}$ ) exhibited significant impacts on morphological, physiological and biochemical traits of A. fruticosa, W was more prominent in influencing those traits when compared with $\mathrm{N}$ and $\mathrm{P}$. The maximum effects on growth-contributing parameters were observed when high level of W (76\% FC) was applied with $52.0 \mathrm{mg} \mathrm{kg}^{-1}$ of $\mathrm{N}$ and $49.0 \mathrm{mg} \mathrm{kg}^{-1}$ of P. This combination of W, N and $\mathrm{P}$ was also highly effective in enhancing the levels of LWP, gas exchange parameters and photosynthetic pigment contents. However, under low doses of W, which might have induced drought stress, A. fruticosa enhanced the accumulation of Pro and the activities of antioxidant enzymes SOD, POD and CAT. These results indicated that $A$. fruticosa employed osmoprotective effects of Pro to overcome osmotic stress and antioxidative roles of SOD, CAT and POD to reduce oxidative stress in order to survive under water-shortage conditions. Collectively, the findings of this study provided valuable and useful information that could be used as effective measures for revegetation and ecological restoration of coal-contaminated subsidence areas in China, and perhaps in other arid and semi-arid areas of the world. However, field studies with a range of plant species using suggested doses of $\mathrm{W}, \mathrm{N}$ and $\mathrm{P}$ (76\% FC, 52.0 $\mathrm{mg} \mathrm{kg}^{-1}, 49.0 \mathrm{mg} \mathrm{kg}^{-1}$, respectively) would be beneficial to ensure improved management and sustainable restoration of coal-spoiled areas.

\section{Methods \\ Plant material and growth conditions}

The coal-mined spoils with topsoil were collected from the Yangchangwan coal mining area $\left(106^{\circ} 35^{\prime} \sim 106^{\circ} 38^{\prime}\right.$ E, $37^{\circ} 59^{\prime} \sim 38^{\circ} 03^{\prime} \mathrm{N}$ ) of Lingwu city, Ningdong, Ningxia province, China. The sample was naturally dried, mixed, and finally sieved to $5 \mathrm{~mm}$. Fourteen (14) $\mathrm{kg}$ of soil was taken to fill up each pot (upper diameter of $32 \mathrm{~cm}$, bottom diameter of $27 \mathrm{~cm}$, and height of $30 \mathrm{~cm}$ ). One-yearold A. fruticosa seedlings with similar height (33.0 \pm 3.0 $\mathrm{cm})$ and stem diameter $(2.8 \pm 0.3 \mathrm{~mm})$ were collected from Hengwang Seedlings Greening Company, Alashan County, Inner Mongolia, China. The plant species were identified based on its characteristics and was approved by the Jilantai Forestry Bureau, Alashan county, Inner Mongolia, China before collection. The collection of coal-mined spoils with topsoil and plant specimens were done in a public right of way, which means no specific permission was required for collecting soil and plant samples, and we have not deposited any voucher specimen. After transplanting one A. fruticosa seedling to each pot in March 2018, all pots were placed in an artifi-

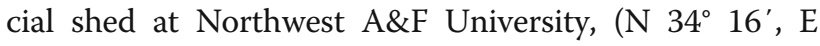
$\left.108^{\circ} 4^{\prime}\right)$, Yangling. The mean annual precipitation and temperature of the experimental site (outside of the artificial shed) were $650 \mathrm{~mm}$ and $13.7^{\circ} \mathrm{C}$, respectively. In the first month, sufficient water was provided to all pots to induce seedling recovery from transplantation stress. One month later, when the water content was close to the lower level of the water threshold, experimental treatments were applied, up to October 2018 according to the experimental design obtained from rsm. The amount of moisture lost from each pot through transpiration and evaporation was determined through a weighing method, and irrigation was done every day during the entire trial period. Fertilizer was applied in holes near the root zone of the seedlings. Nitrogen $(\mathrm{N})$ fertilizer (urea- $46 \% \mathrm{~N}$ ) was applied in four times $(1 / 4 \mathrm{~N}$, May $6^{\text {th }} ; 1 / 4 \mathrm{~N}$, June $6^{\text {th }} ; 1 / 4 \mathrm{~N}$, July $6^{\text {th }} ; 1 / 4 \mathrm{~N}$, August $6^{\text {th }}$ ), whereas phosphorus (P) fertilizer (Triple super phosphate-46\% $\left.\mathrm{P}_{2} \mathrm{O}_{5}\right)$ was applied in two equal half $(1 / 2$ May $6^{\text {th }}$ and $1 / 2$ July $\left.6^{\text {th }}\right)$. Before starting the pot experiment, various soil properties were calculated, and recorded as FC $(11.177 \%)$, soil bulk density $\left(1.48 \mathrm{~g} \mathrm{~cm}^{-3}\right)$, soil $\mathrm{pH}(7.83)$, total $\mathrm{N}\left(0.157 \mathrm{~g} \mathrm{~kg}^{-1}\right)$, available $\mathrm{N}(6.14$ $\mathrm{mg} \mathrm{kg}-1)$, available $\mathrm{P}\left(1.98 \mathrm{mg} \mathrm{kg}^{-1}\right)$ and available $\mathrm{K}$ (66.88 $\mathrm{mg} \mathrm{kg}^{-1}$ ).

\section{Measurement of morphological growth}

Changes in plant height and stem diameter were measured using measuring-tape and slide calliper, respectively, 
at every 15-days-interval throughout the growing seasons. Increase of growth in plant height and stem diameter were calculated by subtracting initial reading from final reading. For the measurement of plant biomass, plant samples were carefully washed with water for removing debris, and different plant parts (leaves, stems, and roots) were separated accordingly. Plant samples were initially dried in an oven for $20 \mathrm{~min}$ at $105^{\circ} \mathrm{C}$, followed by further drying at $80^{\circ} \mathrm{C}$, and finally dry biomass of different plant parts was determined. The maximum root length also measured using a measuring-tape. The root-shoot $(\mathrm{R} / \mathrm{S})$ biomass ratio was measured by below-ground biomass divided by above-ground biomass.

\section{Determination of leaf gas-exchange parameters and leaf water potential}

Leaf gas-exchange parameters, including net photosynthesis rate $\left(P_{\mathrm{n}}\right)$, transpiration rate $\left(T_{\mathrm{r}}\right)$, stomatal conductance $\left(G_{\mathrm{s}}\right)$ and water use efficiency (WUE) were measured on sunny days between 8:30 am and 11:30 am using a Portable Photosynthesis System CIRAS-3 (PP Systems, Amesbury, MA, U.S.A). Three seedlings from each treatment were used for determining gas-exchange parameters. At the time of measurement, photosynthetic active radiations were maintained at $1000 \mu \mathrm{mol} \mathrm{m}^{-2} \mathrm{~s}^{-1}, \mathrm{CO}_{2}$ at $300 \mu \mathrm{mol} \mathrm{mol}^{-1}$, leaf temperature at $25^{\circ} \mathrm{C}$ and relative humidity at $70 \%$ (provided by a built-in red LED light source). Leaf water potential (LWP) of the selected seedlings was determined by PMS-Model 1000 plant water potential meter (PMS Instrument Company, Albany, OR, USA) before 06:00 am.

\section{Estimation of chlorophyll contents}

Chlorophyll (Chl) was extracted from completely expanded fresh leaf samples $(0.1 \mathrm{~g})$ using a $10 \mathrm{~mL}$ mixture of ethanol, acetone and distilled water (4.5:4.5:1) following the method of Chen and Chen [47]. The absorbance of the extracts was taken at 645 and $663 \mathrm{~nm}$, and the contents of Chl $a$, Chl $b$ and total Chl were calculated as mg $\mathrm{g}^{-1}$ fresh weight (FW) by the formula described by Arnon [48].

\section{Measurement of malondialdehyde and proline contents}

The method of Wang et al. [49] was adopted to extract, and determine the contents of malondialdehyde (MDA) in leaf samples of $A$. fruticosa. Extract $(2 \mathrm{~mL})$ was mixed with an equal volume of $0.5 \%$ 2-thiobarbituric acid (TBA, dissolved in 15\% trichloroacetic acid), and the mixture was heated for $30 \mathrm{~min}$ at $100{ }^{\circ} \mathrm{C}$ followed by cooling in an ice bath. The mixture was then centrifuged at $10,000 \mathrm{rpm}$ for $10 \mathrm{~min}$, and the absorbance of the supernatants was read at 450, 532 and $600 \mathrm{~nm}$ using a spectrophotometer. The MDA content was calculated and expressed as $\mu \mathrm{mol} \mathrm{g}^{-1} \mathrm{FW}$.
Free proline (Pro) from fresh leaf samples was extracted using sulphosalicylic acid solution, and measured with ninhydrin according to Bates et al. [50]. The fresh leaf samples $(0.1 \mathrm{~g})$ were extracted with $3 \%$ aqueous sulfosalicylic acid $(10 \mathrm{~mL})$ and placed in water-bath for boiling for $10 \mathrm{~min}$ followed by filtering with Whatman No. 2 filter paper. Plant extract $(2 \mathrm{~mL})$ was mixed with $2 \mathrm{~mL}$ ninhydrin solution and $2 \mathrm{~mL}$ glacial acetic acid, and the mixture was heated for $30 \mathrm{~min}$ at $100^{\circ} \mathrm{C}$, followed by cooling in an ice bath. Toluene $(4 \mathrm{~mL})$ was used to extract proline from the mixture; the content of Pro was measured after taking the absorbance at $520 \mathrm{~nm}$ using a spectrophotometer.

\section{Determination of antioxidant enzyme activities}

Fresh leaf samples $(0.3 \mathrm{~g})$ were homogenized in a mortar and pestle (ice-cold conditions) using $8 \mathrm{~mL}$ of $50 \mathrm{mM}$ sodium phosphate buffer ( $\mathrm{pH} 7.8$ ), and the homogenates were centrifuged at $10,000 \mathrm{rpm}$ for $20 \mathrm{~min}$ at $4{ }^{\circ} \mathrm{C}$. The supernatant was separated and used for the estimation of enzyme activities.

The activity of superoxide dismutase (SOD, EC 1.15.1.1) was determined following the method of Zhang et al. [51]. The reaction mixture contained $3 \mathrm{~mL}$ of phosphate buffer ( $\mathrm{pH} 7.8), 0.6 \mathrm{~mL}$ of $130 \mathrm{mM}$ methionine buffer, $0.6 \mathrm{~mL}$ of $750 \mu \mathrm{M}$ nitroblue tetrazolium buffer, $0.6 \mathrm{~mL}$ of $100 \mu \mathrm{M}$ EDTA-Na buffer, $0.6 \mathrm{~mL}$ of $20 \mu \mathrm{M}$ riboflavin and $0.2 \mathrm{~mL}$ of enzyme extract. The photoreduction of nitroblue tetrazolium was determined at 560 $\mathrm{nm}$ using a spectrophotometer. One unit (U) of SOD activity was equal to the amount of enzyme needed to produce $50 \%$ inhibition of the color reaction.

Catalase (CAT, EC 1.11.1.6) activity was determined following the method reported in Beers and Sizer [52]. The reaction mixture $(2.6 \mathrm{~mL})$ contained $100 \mathrm{mM}$ phosphate buffer (pH 7.0), $20 \mathrm{mM} \mathrm{H}_{2} \mathrm{O}_{2}$ and $100 \mu \mathrm{L}$ enzyme extract. The reduction in $\mathrm{H}_{2} \mathrm{O}_{2}$ was monitored at $240 \mathrm{~nm}$. Enzyme activity was expressed as CAT $\mathrm{U} \mathrm{min}^{-1} \mathrm{~g}^{-1} \mathrm{FW}$.

Peroxidase (POD, EC 1.11.1.7) activity was carried out using the guaiacol oxidation method described by Ekmekci and Terzioglu [53]. Enzyme extract $(20 \mu \mathrm{L})$ was mixed with $3 \mathrm{~mL}$ of $50 \mathrm{mM}$ phosphate buffer ( $\mathrm{pH}$ 6.0) having $20.1 \mathrm{mM}$ guaiacol, $12.3 \mathrm{mM} \mathrm{H}_{2} \mathrm{O}_{2}$, and guaiacol oxidation was measured based on absorbance increase at $470 \mathrm{~nm}$ for $3 \mathrm{~min}$. Enzyme activity was expressed as units of guaiacol oxidized $\mathrm{min}^{-1} \mathrm{~g}^{-1} \mathrm{FW}$.

\section{Experimental design for statistical analysis and optimization}

In our study, response surface methodology (RSM) based on central composite design (CCD) method was used with statistical software design expert (Trial version 11, Stat-Ease Inc., USA). Ranges of independent variables of our study were chosen based on some previous 
Table 4 Factor levels used in central composite design (CCD)

\begin{tabular}{|c|c|c|c|c|c|c|c|}
\hline \multirow[t]{2}{*}{ Independent variables } & \multirow[t]{2}{*}{ Codes } & \multirow[t]{2}{*}{ Symbols } & \multicolumn{5}{|c|}{ Coded and actual values } \\
\hline & & & -1.682 & -1 & 0 & +1 & +1.682 \\
\hline Soil-water (\% FC) & $x_{1}$ & W & 40 & 48.1 & 60 & 71.9 & 80 \\
\hline Nitrogen $(\mathrm{N})$ rate $\left(\mathrm{mg} \mathrm{kg}^{-1}\right)$ & $x_{2}$ & $\mathrm{~N}$ & 0 & 24.32 & 60 & 95.68 & 120 \\
\hline Phosphorus (P) rate $\left(\mathrm{mg} \mathrm{kg}^{-1}\right)$ & $x_{3}$ & $P$ & 0 & 36.49 & 90 & 143.51 & 180 \\
\hline
\end{tabular}

literature [54-56] and presented in Table 4. Different levels $(+\alpha,+1,0,-1,-\alpha)$ of each factor were taken for operating this study. The distances from the centre to axial points are represented by $\alpha$ and calculated by the following equation.

$$
\alpha=\left(2^{\mathrm{k}}\right)^{1 / 4}
$$

Where $\mathrm{k}$ represents the number of factors, and therefore, $\alpha$ value in our study was 1.682. The CCD comprises 20 experimental runs with eight factorial points, six axial points and six replicates at the center points. A total of 80 seedlings subjected to twenty treatments with four repetitions were arranged randomly. Independent variables effects on responses were analyzed by using a second-order polynomial equation:

$$
\begin{aligned}
Y= & a_{0}+a_{1} x_{1}+a_{2} x_{2}+a_{3} x_{3}+a_{4} x_{1} x_{2}+a_{5} x_{1} x_{3} \\
& +a_{6} x_{2} x_{3}+a_{7} x_{1}{ }^{2}+a_{8} x_{2}{ }^{2}+a_{9} x_{3}{ }^{2},
\end{aligned}
$$

Where, $\mathrm{Y}$ is the response variables; $\mathrm{a}_{0}$ is regression constant-coefficient; $a_{1}, a_{2}$ and $a_{3}$ are linear terms; $a_{4}, a_{5}$, and $\mathrm{a}_{6}$ are interaction terms; $\mathrm{a}_{7}, \mathrm{a}_{8}$, and $\mathrm{a}_{9}$ determine quadratic terms; $\mathrm{x}_{1}, \mathrm{x}_{2}$, and $\mathrm{x}_{3}=$ represents the coded value of $\mathrm{W}, \mathrm{N}$, and $\mathrm{P}$.

RSM was carried out to optimize the process variables on the growth and development of A. fruticosa, and the experimental results are presented in Tables 1 and 2 . The relationship between the response variables and process variables was obtained by applying multiple regression analysis. The final models, in terms of coded factors were represented in Table 3. A Positive and negative sign in front of the terms indicated synergistic and antagonistic effects, respectively. To determine the significance and fitness of the model for response variables, analysis of variances (ANOVA) was carried out. The model $F$ and $P$-value were found for different parameters indicated that the model was highly significant. To determine the model precision, the results of the experiment were examined with coefficient of variation $(\mathrm{CV})$, adequate precision (AP) and $\mathrm{R}^{2}$ values. In our present experiment, the adjusted $R$-squared $\left(R_{a}^{2}\right)$ value was detected to be very near and a little bit lesser then $\mathrm{R}^{2}$, which designated a strong correlation between the experimental and predicted values. For reasonable agreement, the difference between predicted R-squared $\left(\mathrm{R}_{p}^{2}\right)$ value and $\mathrm{R}_{a}^{2}$ value should be less than 0.2 [57], and we found that all difference values were less than 0.2 which confirmed that the form of the model chosen to explain the relationship between the factors and the response was well-correlated. 3-D response surface plots obtained from statistical software were designed to find out the relationship between process variables and to assess the response variables over process variables. At the time of creating 3-D response surface plot, we retained our third factor as a central level (as our model comprises three factors).

\section{Supplementary information}

Supplementary information accompanies this paper at https://doi.org/10. 1186/s12870-020-02397-1.

Additional file 1: Figure S1. Response surface plots showing the effect of soil-water $(\mathrm{W})$, nitrogen $(\mathrm{N})$ and phosphorus $(\mathrm{P})$ on the plant height (ab), stem diameter (c-d), root length (e-f), dry biomass $(\mathrm{g})$, and root-shoot $(\mathrm{R} / \mathrm{S})$ biomass ratio (h-i).

Additional file 2: Figure S2. Response surface plots showing the effect of soil-water $(W)$, nitrogen $(N)$ and phosphorus $(P)$ on the leaf water potential (LWP) $(a-b)$, photosynthesis rate $\left(P_{n}\right)(c)$, transpiration rate $\left(T_{r}\right)(d-e)$, stomatal conductance $\left(G_{s}\right)(f-g)$, water use efficiency (WUE) (h-i), chlorophyll a (Chl a) (j-l), chlorophyll b (Chl b) (m-o) and total chlorophyll (Total Chl) content $(p)$

Additional file 3: Figure S3. Response surface plots showing the effect of soil-water $(\mathrm{W})$, nitrogen $(\mathrm{N})$ and phosphorus $(\mathrm{P})$ on the malondialdehyde (MDA) (a) and proline (Pro) (b-c) contents, and activities of superoxide dismutase (SOD) (d-e), catalase (CAT) (f-g), and peroxidase (POD) $(h-i)$.

\section{Abbreviations}

W: Soil-water; N: Nitrogen; P: Phosphorus; R/S ratio: Root to shoot biomass ratio; LWP: Leaf water potential; $P_{n}$ : Photosynthesis rate; $T_{r}$ : Transpiration rate; $G_{s}$ : Stomatal conductance; WUE: Water use efficiency; Chl a: Chlorophyll a; Chl b: Chlorophyll b; total Chl: Total Chlorophyll; FW: Fresh weight; SOD: Superoxide dismutase; CAT: Catalase; POD: Peroxidase; MDA: Malondialdehyde; Pro: Proline; CCD: Central composite design; RSM: Response surface methodology

\section{Acknowledgements}

The authors express their special gratitude to all the funding sources for the financial assistance and also want to thank Feng shulin, Boyuan Li, Xu Ma and Guoli Lv for extending help during sample analysis. We are very grateful to the editor and anonymous reviewers, for very valuable comments that have greatly helped us to further improve the quality of our manuscript.

\section{Authors' contributions}

RR and JXW conceived and designed the experiment; RR performed the experiments; RR and MGM analyzed the data; AS and TS assisted with the experiments; RR, JXW and MGM wrote and revised the manuscript. All authors have read and approved the final manuscript. 


\section{Funding}

This research was financed by National Key Research and Development Program of China "Eco-security technology for coal mining bases in the Northwestern arid desert regions in China" (2017YFC0504400); "Studies on the vegetation rehabilitation and conservation in abandoned coal mining land research" (2017YFC0504402). National Natural Science Foundation Project of China (31670713) and Yulin City Forestry Science and Technology Plan Projects (K403021528). The supporters did not play any role in the design of the study, data collection, and analysis of the data or writing the manuscript.

\section{Availability of data and materials}

The dataset generated and analyzed during the study are available from the corresponding author on reasonable request.

\section{Ethics approval and consent to participate}

Not applicable.

\section{Consent for publication}

Not applicable.

\section{Competing interests}

The authors declare that they have no competing interests.

\section{Author details}

'College of Natural Resources and Environment, Northwest A\&F University, Yangling, Shaanxi 712100, People's Republic of China. ${ }^{2}$ Department of Agroforestry \& Environmental Science, Sylhet Agricultural University, Sylhet 3100, Bangladesh. ${ }^{3}$ Department of Biochemistry and Molecular Biology, Bangabandhu Sheikh Mujibur Rahman Agricultural University, Gazipur 1706 Bangladesh. ${ }^{4}$ Key Laboratory of Plant Nutrition and the Agri-Environment in Northwest China, Ministry of Agriculture, Yangling 712100, People's Republic of China. ${ }^{5}$ School of Economics and Finance, Xi'an Jiaotong University, Xi'an 710049, People's Republic of China.

Received: 8 November 2019 Accepted: 15 April 2020

Published online: 25 April 2020

\section{References}

1. Valladares F, Dobarro I, Sánchez-Gómez D, Pearcy RW. Photoinhibition and drought in Mediterranean woody saplings: scaling effects and interactions in sun and shade phenotypes. J Exp Bot. 2005;56:483-94.

2. Yang C, Luo Y, Sun L, Wu N. Effect of deficit irrigation on the growth, water use characteristics and yield of cotton in arid Northwest China. Pedosphere. 2015;25:910-24

3. Liu Y, Gao M, Wu W, Tanveer SK, Wen X, Liao Y. The effects of conservation tillage practices on the soil water-holding capacity of a non-irrigated apple orchard in the loess plateau, China. Soil Tillage Res. 2013;130:7-12.

4. Wang Y, Shao M, Liu Z. Vertical distribution and influencing factors of soil water content within 21-m profile on the Chinese loess plateau. Geoderma. 2013;193-194:300-10.

5. Yao X, Fu B, Lü Y, Chang R, Wang S, Wang Y, et al. The multi-scale spatial variance of soil moisture in the semi-arid loess plateau of China. J Soils Sediments. 2012;12:694-703.

6. Huang $Y$, Tian F, Wang $Y$, Wang M, Hu Z. Effect of coal mining on vegetation disturbance and associated carbon loss. Environ Earth Sci. 2015, 73:2329-42.

7. Xiao W, Fu Y, Wang T, Lv X. Effects of land use transitions due to underground coal mining on ecosystem services in high groundwater table areas: a case study in the Yanzhou coalfield. Land Use Policy. 2018;71:21321.

8. Mukhopadhyay S, George J, Masto RE. Changes in polycyclic aromatic hydrocarbons (pahs) and soil biological parameters in a revegetated coal mine spoil. Land Degrad Dev. 2017:28:1047-55.

9. Richards RA. Physiological traits used in the breeding of new cultivars for water-scarce environments. Agric Water Manag. 2006;80:197-211.

10. Wang $L$, Ji B, Hu Y, Liu R, Sun W. A review on in situ phytoremediation of mine tailings. Chemosphere. 2017;184:594-600.

11. Toscano S, Farieri E, Ferrante A, Romano D. Physiological and biochemical responses in two ornamental shrubs to drought stress. Front Plant Sci. 2016; 7:645
12. Merwad ARMA, Desoky ESM, Rady MM. Response of water deficit-stressed Vigna unguiculata performances to silicon, proline or methionine foliar application. Sci Hortic. 2018;228:132-44.

13. Blagojević M, Konstantinović B, Samardžić N, Kurjakov A, Orlović S. Seed Bank of Amorpha fruticosa L. on Some Ruderal Sites in Serbia. J Agric Sci Technol B. 2015:5:122-8.

14. Brigić A, Vujčić-Karlo S, Kepčija RM, Stančić Z, Alegro A, Ternjej I. Taxon specific response of carabids (Coleoptera, Carabidae) and other soil invertebrate taxa on invasive plant Amorpha fruticosa in wetlands. Biol Invasions. 2014;16:1497-514.

15. de Quadros PD, Zhalnina K, Davis-Richardson AG, Drew JC, Menezes FB, Flavio $A D$, et al. Coal mining practices reduce the microbial biomass, richness and diversity of soil. Appl Soil Ecol. 2016:98:195-203.

16. Qiu Q, Li J, Wang J, He Q, Dong L, Ma J, et al. Coupling effects of water and fertilizer on seedling growth and nutrient status of Catalpa bungei. J Bei For Uni. 2018;40:58-67.

17. Lin X, Bin O. Coupling effects of water and fertilizer on the biomass of Terminalia mantaly. Trop For. 2015;43:10-3.

18. Kong J, Pei Z, Du M, Sun G, Zhang X. Effects of arbuscular mycorrhizal fungi on the drought resistance of the mining area repair plant Sainfoin. Int J Min Sci Technol. 2014;24:485-9. https://doi.org/10.1016/j.jjmst.2014.05.011.

19. Tang LS, Li Y, Zhang J. Partial rootzone irrigation increases water use efficiency, maintains yield and enhances economic profit of cotton in arid area. Agric Water Manag. 2010;97:1527-33.

20. Devnarain N, Crampton BG, Chikwamba R, Becker JWW, O'Kennedy MM. Physiological responses of selected African sorghum landraces to progressive water stress and re-watering. South African J Bot. 2016;103:61-9.

21. Nonami H. Plant water relations and control of cell elongation at low water potentials. J Plant Res. 1998;111:373-82.

22. Andivia E, Fernández M, Vázquez-Piqué J. Autumn fertilization of Quercus ilex ssp. ballota (Desf.) Samp. Nursery seedlings: effects on morphophysiology and field performance. Ann For Sci. 2011:68:543-53.

23. Cuesta B, Villar-Salvador P, Puértolas J, Jacobs DF, Rey Benayas JM. Why do large, nitrogen rich seedlings better resist stressful transplanting conditions? A physiological analysis in two functionally contrasting Mediterranean forest species. For Ecol Manag. 2010;260:71-8.

24. Chiappero J, del Rosario Cappellari L, Sosa Alderete LG, Palermo TB, Banchio E. Plant growth promoting rhizobacteria improve the antioxidant status in Mentha piperita grown under drought stress leading to an enhancement of plant growth and total phenolic content. Ind Crops Prod. 2019;139:111553. https://doi.org/10.1016/j.indcrop.2019.111553.

25. Niu G, Rodriguez DS. Responses of growth and ion uptake of four rose rootstocks to chloride- or sulfate-dominated salinity. J Am Soc Hortic Sci. 2008;133:663-9.

26. Howard Skinner R, Comas LH. Root distribution of temperate forage species subjected to water and nitrogen stress. Crop Sci. 2010;50:2178-85.

27. Blum A, Shpiler L, Golan G, Mayer J. Yield stability and canopy temperature of wheat genotypes under drought-stress. F Crop Res. 1989;22:289-96.

28. Deng B, Du W, Liu C, Sun W, Tian S, Dong H. Antioxidant response to drought, cold and nutrient stress in two ploidy levels of tobacco plants: low resource requirement confers polytolerance in polyploids? Plant Growth Regul. 2012;66:37-47.

29. Munjonji L, Ayisi KK, Boeckx P, Haesaert G. Stomatal behavior of cowpea genotypes grown under varying moisture levels. Sustain. 2017;10:1-16.

30. Hessini K, Ghandour M, Albouchi A, Soltani A, Werner KH, Abdelly C. Biomass production, photosynthesis, and leaf water relations of Spartina alterniflora under moderate water stress. J Plant Res. 2008:121:311-8.

31. Keshavarz Afshar R, Chaichi MR, Moghadam H, Ehteshami SMR. Irrigation, phosphorus fertilizer and phosphorus solubilizing microorganism effects on yield and forage quality of turnip (Brassica rapa L.) in an arid region of Iran. Agric Res. 2012;1:370-8.

32. Pan J, Liu Y, Zhong X, Lampayan RM, Singleton GR, Huang N, et al. Grain yield, water productivity and nitrogen use efficiency of rice under different water management and fertilizer-N inputs in South China. Agric Water Manag. 2017;184:191-200.

33. Ribeiro RV, Machado EC, Santos MG, Oliveira RF. Photosynthesis and water relations of well-watered orange plants as affected by winter and summer conditions. Photosynthetica. 2009:47:215-22.

34. Riaz A, Younis A, Taj AR, Karim A, Tariq U, Munir S, et al. Effect of drought stress on growth and flowering of marigold (Tagetes erecta L.). Pakistan J Bot. 2013;45(SPL.ISS):123-31. 
35. Hosseinzadeh SR, Amiri H, Ismaili A. Effect of vermicompost fertilizer on photosynthetic characteristics of chickpea (Cicer arietinum L.) under drought stress. Photosynthetica. 2016;54:87-92.

36. Wu FZ, Bao WK, Li FL, Wu N. Effects of water stress and nitrogen supply on leaf gas exchange and fluorescence parameters of Sophora davidii seedlings. Photosynthetica. 2008:46:40-8.

37. Gallé A, Feller U. Changes of photosynthetic traits in beech saplings (Fagus sylvatica) under severe drought stress and during recovery. Physiol Plant. 2007;131:412-21.

38. Çelebi Z, Andiç N, Yilmaz H. Determination of proper species mixtures for established turfgrass field in Van region. J Agr Sci. 2010;20:16-20.

39. Munshaw GC, Ervin EH, Shang C, Askew SD, Zhang X, Lemus RW. Influence of late-season iron, nitrogen, and seaweed extract on fall color retention and cold tolerance of four bermudagrass cultivars. Crop Sci. 2006;46:273-83.

40. Saneoka H, Moghaieb REA, Premachandra GS, Fuijta K. Nitrogen nutrition and water stress effects on cell membrane stability and leaf water relations in Agrostis palustris Huds. Environ Exp Bot. 2004:52:131-8.

41. Garg BK, Kathju S, Burman U. Influence of water stress on water relations, photosynthetic parameters and nitrogen metabolism of moth bean genotypes. Biol Plant. 2001;44:289-92.

42. Molinari HBC, Marur CJ, Daros E, De Campos MKF, De Carvalho JFRP, Filho $J C B$, et al. Evaluation of the stress-inducible production of proline in transgenic sugarcane (Saccharum spp.): osmotic adjustment, chlorophyll fluorescence and oxidative stress. Physiol Plant. 2007;130:218-29.

43. Shao H, Liang Z, Shao M. Changes of anti-oxidative enzymes and MDA content under soil water deficits among 10 wheat (Triticum aestivum $\mathrm{L}$ ) genotypes at maturation stage. Colloids Surf B Biointerfaces. 2005;45:7-13.

44. Hojati M, Modarres-Sanavy SAM, Karimi M, Ghanati F. Responses of growth and antioxidant systems in Carthamus tinctorius L. under water deficit stress. Acta Physiol Plant. 2011;33:105-12.

45. Bhatt D, Negi M, Sharma P, Saxena SC, Dobriyal AK, Arora S. Responses to drought induced oxidative stress in five finger millet varieties differing in their geographical distribution. Physiol Mol Biol Plants. 2011;17:347-53.

46. Wang HJ, Bao YY, Niu TX, Li XF. Effect of combine application of microbial inoculum and fertilizer on fertility of open-pit mine dump reclaimed soil. ACTA Agric Boreali-Sinica. 2014;29:186-91.

47. Chen FM, Chen S. A study on the determination of chlorophyll content by mixed solution method. J Zhejiang For Sci Technol. 1984;1:21-5.

48. Arnon DI. Copper enzymes in isolated chloroplasts. Polyphenoloxidase in Beta vulgaris. Plant Physiol. 1949;24:1-15.

49. Wang J, You Y, Chen W, Xu Q, Wang J, Liu Y, et al. Optimal hypobaric treatment delays ripening of honey peach fruit via increasing endogenous energy status and enhancing antioxidant defence systems during storage. Postharvest Biol Technol. 2015;101:1-9. https://doi.org/10.1016/.jpostharvbio.2014.11.004.

50. Bates $L S$, Waldren RP, Teare ID. Rapid determination of free proline for water-stress studies. Plant Soil. 1973;39:205-7.

51. Zhang WF, Zhang F, Raziuddin R, Gong HJ, Yang ZM, Lu L, et al. Effects of 5-aminolevulinic acid on oilseed rape seedling growth under herbicide toxicity stress. J Plant Growth Regul. 2008;27:159-69.

52. Beers RF, Sizer IW. Article: a spectrophotometric method for measuring the breakdown of hydrogen peroxide. J Biol Chem. 1952;195:133-40.

53. Ekmekci Y, Terzioglu S. Effects of oxidative stress induced by paraquat on wild and cultivated wheats. Pestic Biochem Physiol. 2005;83:69-81.

54. Jia J, Dong Y, Qi Y, Peng Q, Liu X, Sun L, et al. Effects of water and nitrogen addition on vegetation carbon pools in a semi-arid temperate steppe. J For Res. 2016;27:621-9.

55. Zhao R, Guo W, Bi N, Guo J, Wang L, Zhao J, et al. Arbuscular mycorrhizal fungi affect the growth, nutrient uptake and water status of maize (Zea mays L.) grown in two types of coal mine spoils under drought stress. Appl Soil Ecol. 2015;88:41-9.

56. Huang J, Yu H, Lin H, Zhang Y, Searle EB, Yuan Z. Phosphorus amendment mitigates nitrogen addition-induced phosphorus limitation in two plant species in a desert steppe, China. Plant Soil. 2016;399:221-32.

57. Mourabet M, El Rhilassi A, El Boujaady H, Bennani-Ziatni M, El Hamri R, Taitai A. Removal of fluoride from aqueous solution by adsorption on Apatitic tricalcium phosphate using box-Behnken design and desirability function. Appl Surf Sci. 2012;258:4402-10.

\section{Publisher's Note}

Springer Nature remains neutral with regard to jurisdictional claims in published maps and institutional affiliations.

\section{Ready to submit your research? Choose BMC and benefit from:}

- fast, convenient online submission

- thorough peer review by experienced researchers in your field

- rapid publication on acceptance

- support for research data, including large and complex data types

- gold Open Access which fosters wider collaboration and increased citations

- maximum visibility for your research: over $100 \mathrm{M}$ website views per year

At BMC, research is always in progress.

Learn more biomedcentral.com/submissions 